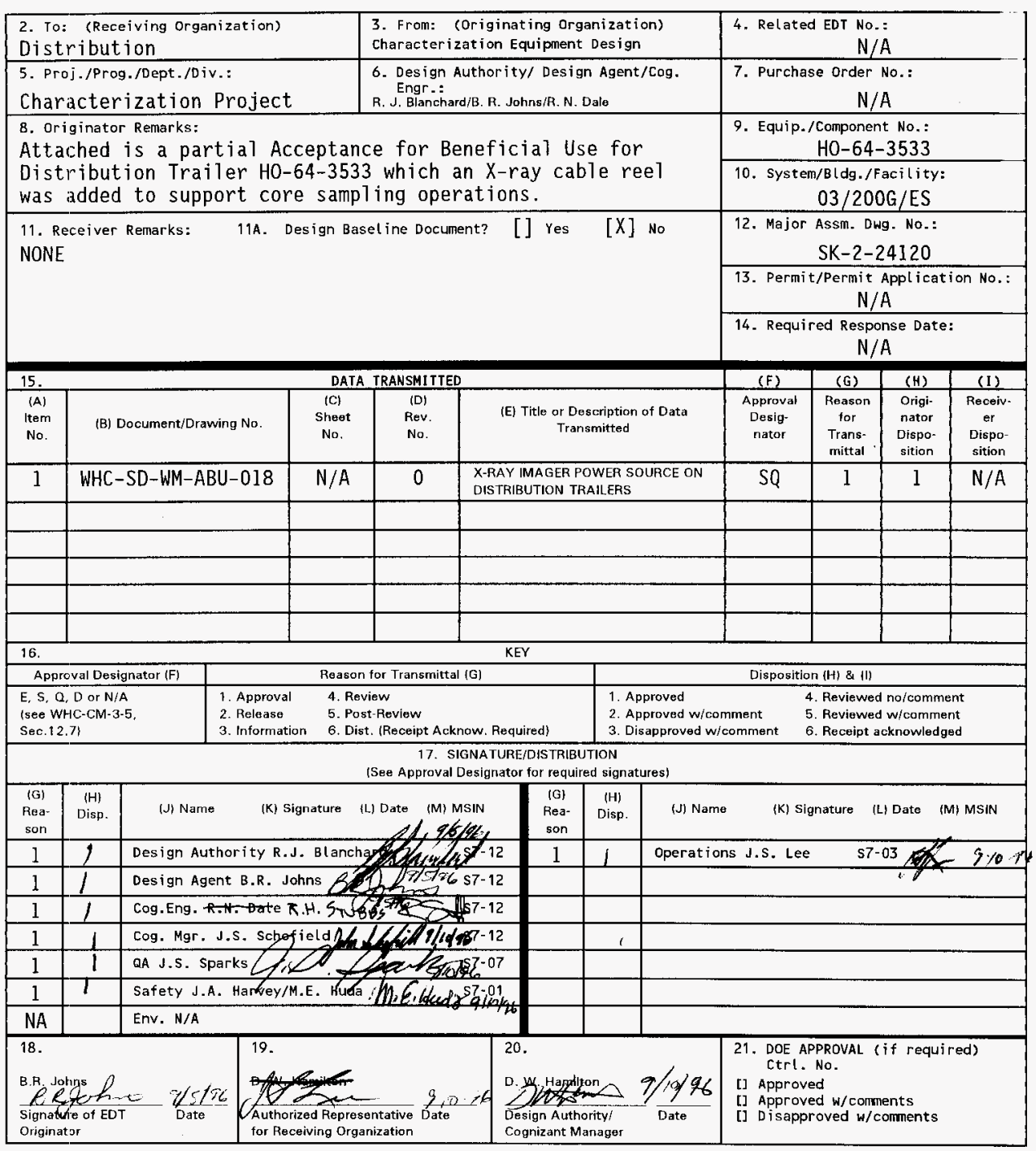

BD - 7400-172-2(05/96) GEF097 


\title{
X-RAY IMAGER POWER SOURCE ON DISTRIBUTION TRAILERS
}

\author{
B. R. JOHNS
}

Westinghouse-Hanford, Rich1 and, WA 99352

U.S. Department of Energy Contract DE-AC06-87RL10930

$\begin{array}{lll}\text { EDT/ECN: } & 617990 & \text { UC: } \\ \text { Org Code: } & 75230 & \text { Charge Code: } \\ \text { B\&R Code: } & \text { EW3120074 } & \text { Total Pages: } 4\end{array}$

Key Words: Electrical, power source, generator, cable reels

Abstract: This Acceptance for Beneficial Use documents the work completed on the addition of an X-ray cable reel on distribution trailer H0-64-3533 for core sampling equipment. Work and documentation remaining to be completed is identified.

TRADEMARK DISCLAIMER. Reference herein to any specific commercial product, process, or service by trade name, tradenark, manufacturer, or otherwise, does not necessarily constitute or imply its endorsement, recommendation, or favoring by the United States Government or any agency thereof or its contractors or subcontractors.

Printed in the United States of America. To obtain copies of this document, contact: WHC/BCS Document Control Services, P.0. Box 1970, Mailstop H6-08, Richland WA 99352, Phone (509) 372-2420; Fax (509) 376-4989.
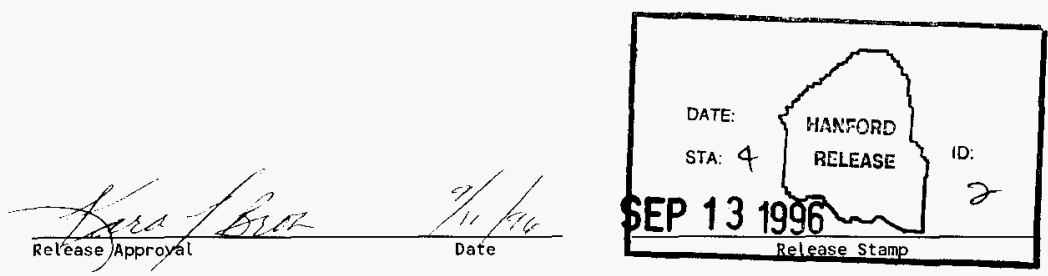

\section{Approved for Public Release}


WHC-SD-WM-ABU-018, REVISION 0

ACCEPTANCE FOR BENEFICIAL USE(ABU)

1. Document Title: X-Ray Imager Power Source on Distribution Trailers 3 and 4 .

2. Engineering Task No.: ETN 95-0048

3. Document No.: WHC-SD-WM-ETP-155

4. Project No.: ES-95-362

5. Approva1 Designator: SQ

6. System/Bldg/Facility: 03/2704HV/Core Sampling

7. Equipment/Component No.: HO-64-3532/HO-64-3533

8. ECN/EDT No.: EDT 615421

9. Final $A B U$

Partial ABU $X$

10. ATP Rerun Required: [] Yes [X] No

11. Description of work completed:

This ABU verifies completion of the installation of an X-ray cable reel on distribution trailer H0-64-3533 under work package ES-95-362. The new cable reel on the trailer provides a dedicated power source of $240 / 120 \mathrm{vac}, 70$ amperes for the $X$-ray cart. The connector on the end of the power cable is physically different thus preventing the incorrect power source from being connected to the X-ray or the X-ray power from being connected to another piece of sampling equipment.

12. EXCEPTIONS:

12.1 An $X$-ray cable reel needs to be added to distribution trailer H0-64-3532.

12.2 The plug on the remaining $X$-ray carts must be changed to match the new connector on the $X$-ray cable reel.

13. Acceptance Test and Inspections:

13.1 Inspection and testing of the $X$-ray cable reel was completed under work package ES-95-362. 
WHC-SD-WM-ABU-018, REVISION 0

14. Documents or Other Items/Tasks to be Completed or Updated:

14.1 See Attachment A for list of items.

14.2 Items to be completed:

a. Spare parts - Add spares to Spare Parts Inventory and order parts. Responsible: B. R. Johns Completion: Upon completion of both trailers \#3 and \#4.

b. Preventative Maintenance(PM) - Add X-ray reel checks to PM 6ES419. 
WHC-SD-WM-ABU-018, REVISION 0

ATTACHMENT A

DOCUMENTATION REQUIRED FOR ACCEPTANCE FOR BENEFICIAL USE

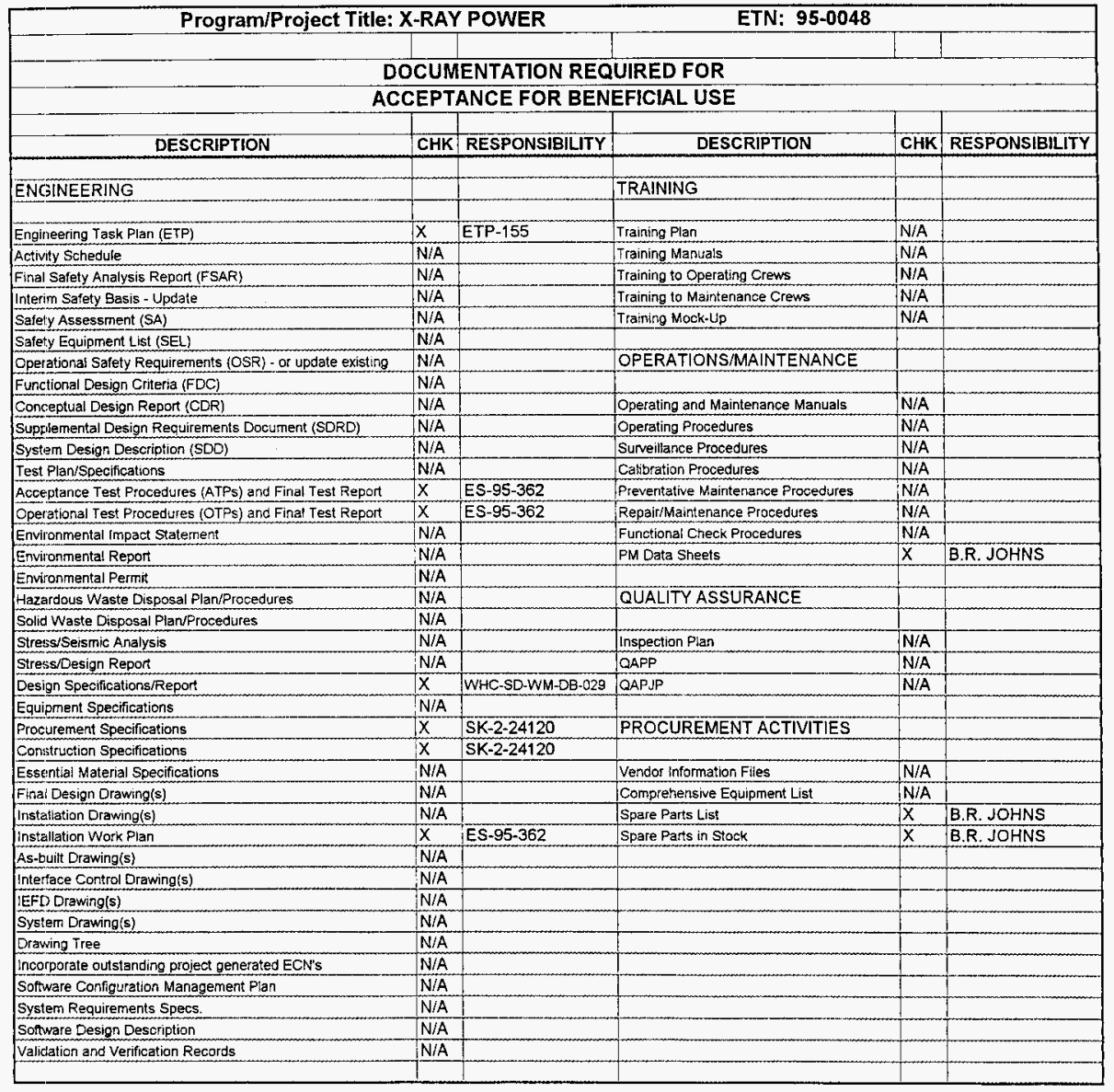

